\title{
CHARACTERIZATION OF RESIDUES FROM PLANT BIOMASS FOR USE IN ENERGY GENERATION
}

\author{
Luana Elis de Ramos e Paula ${ }^{1}$, Paulo Fernando Trugilho², Alfredo Napoli ${ }^{3}$, Maria Lúcia Bianchi ${ }^{4}$
}

(received: March 15, 2010; accepted: February 25, 2011)

\begin{abstract}
The use of plant residues for energy purposes is already a reality, yet in order to ensure suitability and recommend a given material as being a good energy generator, it is necessary to characterize the material through chemical analysis and determine its calorific value. This research aimed to analyze different residues from plant biomass, characterizing them as potential sources for energy production. For the accomplishment of this study, the following residues were used: wood processing residue (sawdust and planer shavings); coffee bean parchment and coffee plant stem; bean stem and pod; soybean stem and pod; rice husk; corn leaf, stem, straw and cob; and sugar cane straw and bagasse. For residue characterization the following analyses were done: chemical analysis, immediate chemical analysis, calorific value and elemental analysis. All procedures were conducted at the Laboratory of Forest Biomass Energy of the Federal University of Lavras. In general, all residues showed potential for energetic use. Rice husk was found to have higher lignin content, which is an interesting attribute as far as energy production is concerned. Its high ash content, however, led to a reduction in calorific value and fixed carbon. The remaining residues were found to have similar energetic characteristics, with corn cob showing greater calorific value, followed by coffee plant stem, both also containing higher levels of carbon and fixed carbon. A high correlation was found of higher calorific value with volatile materials, carbon and hydrogen contents.
\end{abstract}

Key words: Lignocellulosic residues, chemical analysis, calorific value, bioenergy.

\section{CARACTERIZAÇÃO DE RESÍDUOS DE BIOMASSA VEGETAL PARA UTILIZAÇÃO ENERGÉTICA}

\begin{abstract}
RESUMO: A utilização de resíduos vegetais para fins energéticos já é uma realidade, porém, para afirmar e indicar um determinado material como bom gerador de energia, é necessário caracterizá-lo através de análises químicas e da determinação de seu valor calórico. Objetivou-se, com este trabalho, analisar diferentes resíduos de biomassa vegetal, caracterizando-os como potenciais para a produção de energia. Para a realização deste trabalho, foram utilizados os seguintes resíduos: resíduos do processamento da madeira (serragem e maravalha); pergaminho do grão e caule do cafeeiro; caule e vagem do feijão; caule e vagem da soja; casca de arroz; folha, caule, palha e sabugo de milho e palha e bagaço da cana-de-açúcar. Para a caracterização dos resíduos, foram realizadas as seguintes análises: análise química, análise química imediata, poder calorífico e análise elementar. Todas as análises foram conduzidas no Laboratório de Energia da Biomassa Florestal da Universidade Federal de Lavras. De forma geral, todos os resíduos apresentaram potencial para serem utilizados na produção de energia. A casca de arroz apresentou o maior teor de lignina, característica interessante para produção de energia. No entanto, o seu alto teor de cinza acarretou uma redução no poder calorífico e carbono fixo. Os demais resíduos apresentaram características semelhantes do ponto de vista energético, com destaque para o sabugo de milho, que apresentou maior poder calorífico, seguido do caule do café, ambos continham também maior quantidade de carbono e carbono fixo. O poder calorífico superior apresentou alta correlação com o teor de materiais voláteis, carbono e hidrogênio.
\end{abstract}

Palavras-chave: Resíduos lignocelulósicos, análise química, poder calorífico, bioenergia.

\section{INTRODUCTION}

Brazil is a leading forest and agricultural producer for a variety of reasons, including area availability for cultivation, possibility of introducing assorted cultures, geographic position favoring intense solar radiation throughout the year, tropical climate, besides its extremely rich biodiversity and advanced technology, all of which allow Brazil to hold a privileged position in the field of agrarian sciences.

\footnotetext{
${ }^{1}$ Forest Engineer, PhD candidate in Wood Science and Technology - Departamento de Ciências Florestais - Universidade Federal de Lavras Cx. P. 3037 - 37200-000 - Lavras, MG, Brasil - luanafloresta@hotmail.com

${ }^{2}$ Forest Engineer, Professor, Dr. in Forest Science - Departamento de Ciências Florestais - Universidade Federal de Lavras - Cx. P. 3037 37200-000 - Lavras, MG, Brasil - trugilho@dcf.ufla.br

${ }^{3}$ Materials Scientist, Researcher Dr. - CIRAD - BIOS Department - TAA-39 - Genetic diversity and breeding of forest species - 73 rue Jean-François Breton - 34398 - Montpellier, France - alfredo.napoli@cirad.fr

${ }^{4}$ Chemist, Professor, Dr. in Chemistry - Departamento de Química - Universidade Federal de Lavras - Cx. P. 3037 - 37200-000 - Lavras, MG, Brasil bianchi@dqi.ufla.br
} 
As a result, Brazil has become one of the world's largest producers of wood and agricultural products and is known by many as 'the barn of the world'. In spite of that, intensive production generates large amounts of residue and that can cause serious environmental problems.

According to Vale and Gentil (2008), residue can be defined as any discarded material from activities relating to a production process, being a potential hazard to the environment and, consequently, to society. By contrast, residues can go from being a hazardous risk to becoming generators of profit if they are turned into raw materials for other processes, reducing both the price and the demand for the main product.

Wood is an important input whose value has increased in past decades, yet it is not being used fully (RIBEIRO; ANDRADE, 2005). According to Lima and Silva (2005), every process involving wood transformation generates residues but only $40 \%$ to $60 \%$ of the total volume of logs harvested is actually used.

The processing of agricultural crops also generates large amounts of residue. According to Instituto Brasileiro de Geografia e Estatística - IBGE (2006), in 2006 alone Brazil produced around 11 million tons of bulk, unprocessed rice which in turn generated 2.6 million tons of rice husk. Rocha et al. (2006) argue that the ratio of processed coffee beans to residue can reach 50\%. According to Macedo (2001), each ton of sugar cane (culm) produces $140 \mathrm{~kg}$ (dry matter) of bagasse, $150 \mathrm{~kg}$ of sugar and $140 \mathrm{~kg}$ (dry matter) of stubble, lost from field burns. According to Chagas et al. (2007), residue from bean crops includes straw and stalk, making up 60\% (in weight) of the crop. Soybean is produced on a larger scale in Brazil and thus generates an equally larger amount of residue. According to Bose and Martins Filho (1984), soybean stubble corresponds to as much as $120 \%$ to $150 \%$ of soybean weight.

Lignocellulosic residue can be reused as raw material in a different process from the original process, for instance, it can be used energetically for generation of heat or electricity in generator groups or thermoelectric plants (QUIRINO, 2003).

According to Vale and Gentil (2008), biomass residues are solid fuels that can be used directly as they are, under moisture controlled conditions, and be transformed by mechanical processes into small particles such as wood chips or sawdust, or else pressed into briquettes.

Cerne, Lavras, v. 17, n. 2, p. 237-246, abr./jun. 2011
The use of residues from plant biomass for energy purposes is already a reality. However, in order to ensure suitability and recommend a given material as being a good energy generator it is necessary to characterize the material through chemical analysis and determine its calorific value.

Thus the objective of this work is to analyze different lignocellulosic residues, characterizing them as potential sources for energy production.

\section{MATERIAL AND METHODS}

In order to conduct this study, lignocellulosic residues were obtained in the municipality of Lavras/MG, including wood processing residues (planer shavings and sawdust), coffee bean parchment and coffee plant stem, bean stem and pod, soybean stem and pod, rice husk, corn leaf, stem, straw and cob, plus sugar cane straw and bagasse. The residues were submitted to analysis at the Laboratory of Forest Biomass Energy of the Federal University of Lavras.

The material was ground by a Wiley blade apparatus, using the fraction that passed through a 40 mesh screen but was retained in a 60-mesh screen. The residues were stored under controlled temperature (20 $\pm 3)^{\circ} \mathrm{C}$ and relative humidity $(65 \pm 2) \%$ for moisture homogenization.

An elemental analysis was performed to start with for determination of carbon, hydrogen, nitrogen, sulfur and, by difference, oxygen contents of the material. For that, approximately $2 \mathrm{mg}$ of residue was weighed in a tin sample holder. The aggregate (residue + sample holder) was then placed in the carousel of an Elementar ${ }^{\circledR}$ elemental analyzer. The analysis was performed on one sample at a time. The gases necessary for the operation included helium, used as carrier gas, and oxygen, used as ignition gas. The temperature of the combustion tube, which is located inside the equipment, at the moment the sample was fed into the carousel was $1,150{ }^{\circ} \mathrm{C}$. After combustion, gases were stripped to the reduction tube and then to the detection column. Elements were determined by a thermal conductivity detector whereby each element interacted and had its specific peak. The computer coupled to the equipment made the relevant calculations and derived values expressed as percentage.

The determination of silicon content in rice husk was done using the molybdenum colorimetric method, according to Furlani and Gallo (1978). 
The chemical analysis followed Standards M3/89, M11/77 and M70/71 of Associação Brasileira Técnica de Celulose e Papel - ABTCP (1974), for determination of extractives content, ash content and lignin content respectively. The holocellulose content $(\mathrm{H})$ was done on the basis of Equation 1, using percentage in relation to dry matter of components.

$$
H(\%)=100-E T(\%)-L I(\%)-C I(\%)
$$

where:

$E T=$ extractives total;

$L I=$ lignin;

$C I=$ ash.

The immediate chemical analysis was based on Standard 8112 of Associação Brasileira de Normas Técnicas - ABNT (1983), to determine volatile materials and ash content. Fixed carbon content (CF) was derived from the difference (Equation 2).

$$
C F(\%)=100-M V(\%)-C I(\%)
$$

where:

$M V=$ volatile materials;

$C I=$ ash.

Table 1 - Elemental analysis of residues.

\begin{tabular}{|c|c|c|c|c|c|c|c|c|}
\hline \multirow{2}{*}{\multicolumn{2}{|c|}{ Material }} & \multicolumn{7}{|c|}{ Elements (\%) } \\
\hline & & $\mathrm{C}$ & $\mathrm{H}$ & $\mathrm{N}$ & $\mathrm{S}$ & $\mathrm{O}$ & $\mathrm{C} / \mathrm{H}$ & $\mathrm{C} / \mathrm{N}$ \\
\hline Rice & Grain husk & 39,1 & 5.8 & 0.3 & 0.1 & 54.7 & 6.7 & 130.3 \\
\hline \multirow{2}{*}{ Coffee } & Plant stem & 48.6 & 6.8 & 0.5 & 0.1 & 44.0 & 7.2 & 97.0 \\
\hline & Bean parchment & 47.2 & 6.9 & 0.5 & 0.2 & 45.1 & 6.8 & 94.4 \\
\hline \multirow{2}{*}{ Sugar cane } & Bagasse & 45.3 & 6.8 & 0.5 & 0.3 & 47.1 & 6.7 & 90.6 \\
\hline & Straw & 44.6 & 6.6 & 0.3 & 0.4 & 48.1 & 6.8 & 148.7 \\
\hline \multirow{2}{*}{ Bean } & Stem & 44.3 & 6.6 & 0.7 & 0.3 & 48.1 & 6.7 & 63.3 \\
\hline & Pod & 41.8 & 6.5 & 0.9 & 0.3 & 50.5 & 6.4 & 46.4 \\
\hline \multirow{2}{*}{ Wood } & Sawdust & 48.2 & 6.5 & 0.1 & 0.2 & 45.1 & 7.4 & 482.0 \\
\hline & Planer shavings & 47.3 & 6.6 & 0.1 & 0.2 & 45.8 & 7.2 & 473.0 \\
\hline \multirow{4}{*}{ Corn } & Stem & 45.6 & 6.5 & 0.9 & 0.3 & 46.8 & 7.0 & 50.7 \\
\hline & Leaf & 45.4 & 6.8 & 0.9 & 0.3 & 46.5 & 6.7 & 50.4 \\
\hline & Straw & 44.8 & 6.8 & 0.3 & 0.1 & 47.9 & 6.6 & 149.3 \\
\hline & Cob & 45.5 & 6.7 & 0.5 & 0.3 & 47.0 & 6.8 & 91.0 \\
\hline \multirow{2}{*}{ Soybean } & Stem & 45.7 & 6.6 & 0.6 & 0.1 & 47.0 & 6.9 & 76.2 \\
\hline & Pod & 42.5 & 6.5 & 1.6 & 0.3 & 49.0 & 6.5 & 26.6 \\
\hline
\end{tabular}

Tabela 1 - Análise elementar dos resíduos avaliados.
The analysis for determination of higher calorific value was performed in a Parr ${ }^{\circledR}$ calorimeter, following standard 8633, ABNT (1984). Determination of lower calorific value (PCI) was based on Equation 3.

$$
P C I=P C S-5.72 *(9 H+U)
$$

where:

PCS = higher calorific value;

$H=$ Hydrogen $(\%)$;

$U=$ Moisture (\%).

An analysis of correlation was performed to verify associations between the characteristics being analyzed.

\section{RESULTS AND DISCUSSION}

Table 1 provides elemental analysis results for residues.

In analyzing Table 1 it is noted that the sulfur content was low for all residues, ranging from $0.1 \%$ to $0.4 \%$. The presence of sulfur in fuels is undesirable due to erosion problems and release of $\mathrm{SO}_{2}$ gas after combustion.

Table 2 provides reference values for the elemental analysis of some residues. 
Table 2 - Reference values for elemental analysis.

Tabela 2 - Valores de referência para a análise elementar.

\begin{tabular}{|c|c|c|c|c|c|c|c|}
\hline \multirow{2}{*}{\multicolumn{2}{|c|}{ Material }} & \multicolumn{5}{|c|}{ Elemental analysis (\%) } & \multirow{2}{*}{ Reference } \\
\hline & & $\mathrm{C}$ & $\mathrm{H}$ & $\mathrm{N}$ & $\mathrm{S}$ & $\mathrm{O}$ & \\
\hline Rice & Grain husk & 40.96 & 4.30 & 0.40 & 0.02 & - & Jenkins (1990) \\
\hline Coffee & Bean parchment & 44.00 & 5.40 & 0.70 & - & 49.90 & Brum et al. (2008) \\
\hline \multirow{2}{*}{ Sugar cane } & Bagasse & 46.70 & 5.90 & 0.90 & - & 46.50 & \multirow{2}{*}{ Seye et al. (2003) } \\
\hline & Straw & 43.42 & 5.71 & 1.23 & - & 49.64 & \\
\hline Bean & Straw & 41.50 & 5.90 & 0.60 & - & 52.00 & Oliveira (2009) \\
\hline Wood & Residue & 48.06 & 6.03 & 0.70 & - & 45.21 & Seye et al. (2003) \\
\hline \multirow{3}{*}{ Corn } & Stem + Leaf & 41.90 & 5.30 & 0.00 & - & 46.00 & \multirow{2}{*}{ Raveendran et al. (1995) } \\
\hline & Cob & 47.60 & 5.00 & 0.00 & - & 44.60 & \\
\hline & Straw & 45.80 & 4.50 & 0.75 & - & 48.90 & Bianchi (1995) \\
\hline
\end{tabular}

Rice husk had higher oxygen content and lower carbon and hydrogen contents, being in agreement with Jenkins (1990).

Elemental analysis results for coffee plant stem and coffee bean parchment were similar to results for wood residues, except nitrogen content, found higher in coffee residues. Lower nitrogen content in wood residues resulted in a high $\mathrm{C} / \mathrm{N}$ ratio. Analysis values for coffee bean parchment are in agreement with Brum et al. (2008).

Sugar cane bagasse and straw, as well as wood residues, showed similar results to those by Seye et al. (2003).

The elemental analysis of bean straw (stem + pod), as conducted by Oliveira (2009), provided similar results to results found in this study.

The percentages of corn stem and leaf elements are in agreement with Raveendran et al. (1995), who also studied corn plant (stem + leaf). Results for corn cob and straw were similar to the literature result in Table 2.

A higher $\mathrm{C} / \mathrm{N}$ ratio was observed for sawdust, as shown in Table 1, followed by planer shavings, both of which being wood residues. According to Munalula and Meincken (2009) the higher nitrogen content is related to environmental impacts and air pollution as a function of the formation of toxic nitrogen oxides and nitric acid.

Table 3 provides average values of total extractives, lignin, ash and holocellulose contents found in the residues being assessed. Rice husk was found to have lower extractives content and higher ash content, in comparison with other residues. The high ash content is associated with a large amount of silica $\left(\mathrm{SiO}_{2}\right)$; the analysis detected $8.32 \%$ of silica. The lignin content obtained by
Reyes et al. (1997) for rice husk was similar to findings in this research, unlike ash content. Additionally, rice husk showed a low holocellulose content, in association with its high ash content.

The reference values for these analyses are provided in Table 4. The result found for ash content in coffee plant stem is close to the result found by Pereira (2008), and bean parchment values were found similar to those in literature.

The extractives content found in cane bagasse differed from the finding of Pitarelo (2007), possibly because in his experiment the sugar cane originating the bagasse was burned and washed prior to being ground. The lignin content was similar to the value found by Marabezi et al. (2009).

The chemical analysis of bean residues (Table 3) provided differing component percentages for stem and pod; the broadest difference found was in extractives and lignin contents. From Table 4 it is noted that prior studies consider the aggregate straw (stem + pod) for analysis.

As for the chemical analysis of planer shavings and sawdust, no significant difference was found, and values are in agreement with results found by Mori et al. (2002) and Trugilho et al. (2003).

The chemical analysis of corn stem and leaf provided similar results, the same occurring for straw and cob, except the lignin content for the latter two.

The chemical analysis of soybean residues, stem and pod, provided differing values. The ash content of pod is in agreement with Silva et al. (2008). The values found for soybean were not very dissimilar to bean values, though that was expected as both belong to the pulse family.

Cerne, Lavras, v. 17, n. 2, p. 237-246, abr./jun. 2011 
Table 3 - Chemical analysis of residues.

Tabela 3 - Análise química dos resíduos avaliados.

\begin{tabular}{lccccc}
\hline & Material & Extractives (\%) & Lignin (\%) & Ash (\%) & Holocellulose (\%) \\
\hline \multirow{2}{*}{ Rice } & Grain husk & 4.06 & $26.90 *$ & 16.43 & 52.61 \\
\hline \multirow{2}{*}{ Coffee } & Plant stem & 10.49 & 22.88 & 1.12 & 65.51 \\
& Bean parchment & 7.63 & 23.04 & 1.46 & 67.87 \\
\hline \multirow{2}{*}{ Sugar cane } & Bagasse & 31.76 & 20.88 & 0.80 & 46.56 \\
& Straw & 9.18 & 20.85 & 4.32 & 65.65 \\
\hline \multirow{2}{*}{ Bean } & Stem & 7.55 & 21.61 & 4.61 & 66.23 \\
& Pod & 18.19 & 11.99 & 6.65 & 63.17 \\
\hline \multirow{2}{*}{ Wood } & Sawdust & 9.37 & 21.88 & 0.18 & 68.57 \\
& Planer shavings & 5.60 & 20.62 & 0.13 & 73.65 \\
\hline \multirow{2}{*}{ Corn } & Stem & 11.31 & 20.49 & 3.43 & 64.77 \\
& Leaf & 10.51 & 19.26 & 3.53 & 66.70 \\
& Straw & 5.85 & 9.29 & 1.58 & 83.28 \\
\multirow{2}{*}{ Soybean } & Cob & 5.85 & 15.75 & 1.16 & 77.24 \\
\hline
\end{tabular}

* Adjusted value, deducting $8.32 \%$ of silicon.

Table 4 - Reference values for chemical analysis.

Tabela 4 - Valores de referência para análise química.

\begin{tabular}{|c|c|c|c|c|c|c|}
\hline \multirow{2}{*}{\multicolumn{2}{|c|}{ Material }} & \multicolumn{4}{|c|}{ Chemical analysis (\%) } & \multirow{3}{*}{$\begin{array}{c}\text { Reference } \\
\text { Reyes et al. (1997) }\end{array}$} \\
\hline & & Extr. & Lign. & Ash & Hol. & \\
\hline Rice & Grain husk & - & 29.40 & 8.50 & - & \\
\hline \multirow{3}{*}{ Coffee } & Plant stem & - & - & 0.68 & - & Pereira (2008) \\
\hline & \multirow{2}{*}{ Bean parchment } & 7.00 & 20.00 & 1.37 & 76.00 & Brum (2007) \\
\hline & & - & 24.50 & 0.50 & 66.20 & Brahan and Bressani (1978) \\
\hline \multirow{4}{*}{ Sugar cane } & \multirow{2}{*}{ Bagasse } & 6.80 & 30.00 & 2.40 & - & Pitarelo (2007) \\
\hline & & - & 19.25 & - & - & Marabezi et al. (2009) \\
\hline & \multirow{2}{*}{ Straw } & 11.5 & 39.70 & 11.70 & - & Pitarelo (2007) \\
\hline & & - & 19.10 & - & - & Marabezi et al. (2009) \\
\hline \multirow{2}{*}{ Bean } & \multirow{2}{*}{ Pod+Straw } & 22.7 & 8.40 & - & 71.70 & Brum et al. (2006) \\
\hline & & - & - & 4.30 & - & Oliveira (2009) \\
\hline \multirow[t]{2}{*}{ Wood } & $\begin{array}{l}\text { E. grandis } \\
\text { E. saligna }\end{array}$ & 6.71 & 31.77 & 0.17 & 61.52 & Trugilho et al. (2003) \\
\hline & E. urophylla & 9.15 & 26.70 & 0.16 & 63.62 & Mori et al. (2002) \\
\hline \multirow{3}{*}{ Corn } & Leaf & - & 12.60 & - & 72.00 & \multirow{2}{*}{ Cruz et al. (2000) } \\
\hline & Cob & - & 20.30 & - & 66.40 & \\
\hline & Straw & - & 8.79 & 1.52 & 57.49 & Salazar et al. (2005) \\
\hline Soybean & Pod & - & - & 8.90 & - & Silva et al. (2008) \\
\hline
\end{tabular}

Extr., Lign., Ash, Hol. = Extractives, lignin, ash and holocellulose contents. 
Results of immediate analysis and higher calorific value of residues are provided in Table 5. Table 6 contains reference values for these analyses.
The immediate analysis and calorific value of rice husk are in agreement with Diniz et al. (2004), Jenkins (1990) and Souza et al. (2005).

Table 5 - Immediate analysis and calorific value of residues.

Tabela 5 - Análise imediata e poder calorífico dos resíduos avaliados.

\begin{tabular}{lccccc}
\hline \multirow{2}{*}{\multicolumn{2}{c}{ Material }} & \multicolumn{2}{c}{ Immediate analysis (\%) } & \multicolumn{2}{c}{ Calorific value (cal/g) } \\
\cline { 3 - 6 } Rice & Grain husk & 66.36 & 17.30 & 3812.30 & 3445.08 \\
\hline \multirow{2}{*}{ Coffee } & Plant stem & 80.39 & 19.33 & 4544.00 & 4125.30 \\
& Bean parchment & 79.14 & 19.90 & 4441.74 & 4017.89 \\
\hline \multirow{2}{*}{ Sugar cane } & Bagasse & 82.31 & 17.16 & 4274.48 & 3855.78 \\
& Straw & 78.64 & 17.46 & 4315.66 & 3907.25 \\
\hline \multirow{2}{*}{ Bean } & Stem & 77.53 & 18.75 & 4488.74 & 4080.33 \\
& Pod & 76.65 & 18.10 & 4218.53 & 3815.27 \\
\hline \multirow{2}{*}{ Wood } & Planer & 83.19 & 16.66 & 4291.71 & 3888.45 \\
& Sawdust & 78.89 & 21.03 & 4435.04 & 4026.63 \\
\hline \multirow{2}{*}{ Corn } & Stem & 76.82 & 20.47 & 4211.88 & 3808.62 \\
& Leaf & 78.30 & 18.43 & 4464.52 & 4045.82 \\
& Straw & 81.68 & 17.05 & 4443.38 & 4024.68 \\
\multirow{2}{*}{ Soybean } & Cob & 81.31 & 18.32 & 4615.26 & 4201.70 \\
\hline
\end{tabular}

Table 6 - Reference values for immediate analysis and calorific value.

Tabela 6 - Valores de referência para análise imediata e poder calorífico.

\begin{tabular}{|c|c|c|c|c|c|}
\hline \multirow{2}{*}{\multicolumn{2}{|c|}{ Material }} & \multicolumn{2}{|c|}{ Immediate Analysis } & \multirow{2}{*}{ PCal (cal/g) } & \multirow{2}{*}{ Reference } \\
\hline & & Volatile Materials (\%) & Fixed Carbon (\%) & & \\
\hline \multirow{3}{*}{ Rice } & \multirow{3}{*}{ Grain husk } & 64.30 & 11.90 & - & Souza et al. (2005) \\
\hline & & 65.47 & 16.67 & 3852.00 & Jenkins (1990) \\
\hline & & - & - & 3908.00 & Diniz et al. (2004) \\
\hline \multirow{3}{*}{ Sugar cane } & \multirow{2}{*}{ Bagasse } & 73.78 & 14.95 & 4139.00 & Jenkins (1990) \\
\hline & & 69.39 & 16.10 & - & \multirow{2}{*}{ Seye et al. (2003) } \\
\hline & Straw & 66.40 & 16.35 & - & \\
\hline \multirow{2}{*}{ Wood } & Eucalyptus & 74.10 to 89.90 & 9.60 to 24.30 & - & Brito and Barrichello (1978) \\
\hline & Dry wood & - & - & 4000 to 4800 & Brito (1993) \\
\hline \multirow{4}{*}{ Corn } & Stem + leaf & 80.10 & 13.10 & 3956.94 & \multirow{2}{*}{ Raveendran et al. (1995) } \\
\hline & \multirow{2}{*}{ Cob } & 85.40 & 11.80 & 3744.02 & \\
\hline & & 80.10 & 18.54 & 4498.00 & Jenkins (1990) \\
\hline & Straw & - & - & 3730.00 & Quirino et al. (2005) \\
\hline Soybean & Pod & 63.50 & 27.70 & - & Silva et al. (2008) \\
\hline
\end{tabular}

Cerne, Lavras, v. 17, n. 2, p. 237-246, abr./jun. 2011 
The immediate analysis of coffee plant stem and coffee bean parchment provided similar results to wood results.

The values determined in this study for sugar cane bagasse are in agreement with Jenkins (1990) and Seye et al. (2003), except volatile materials content.

Sugar cane straw was found to have similar fixed carbon value and calorific value to bagasse. Seye et al. (2003) observed lower fixed carbon contents than this study.

The immediate analysis results for bean residues, stem and pod, provided similar values of volatile materials and fixed carbon. The calorific value of the stem was slightly higher, possibly due to its higher lignin content.

The calorific value of wood residues is within the range determined by Brito (1993) and Brito and Barrichello (1978), as provided in Table 6.

The immediate analysis of corn stem and leaf provided similar results of volatile materials to values found by Raveendran et al. (1995), who studied corn plant as an aggregate, in other words, stem plus leaf. The volatile materials content in corn cob was similar to literature results, unlike ash content and calorific value. The immediate analysis and calorific value of corn cob are in agreement with Jenkins (1990). Quirino et al. (2005) observed an inferior calorific value for cob straw.

Results for soybean residues proved similar to results for bean residues. Silva et al. (2008) observed a higher fixed carbon value for soybean pod than this study did.

The lower calorific value is within the expected range for lignocellulosic materials. Corn cob provided the highest value and rice husk, the lowest.

In observing results of residue analyses, dissimilarity is observed, in most cases, in relation to literature results. According to Brum (2007), it should be taken into account that the chemical constitution of materials is conditional on several factors, including soil composition, climate, harvest season, disease and weed presence, planting method, among others, all of which can cause even plants of the same species to differ in composition. Differences may also occur in the way the material is sampled and in the analysis methodology. Additionally, by their very nature, residues are remainders of other processes and thus may well be contaminated or stored unsuitably.

The most significant coefficients of correlation for the characteristics being assessed in residues are provided in Table 7.
Table 7 - Main coefficients of correlation between assessed characteristics.

Tabela 7 - Principais coeficientes de correlação entre as características avaliadas nos resíduos.

\begin{tabular}{lc}
\hline Variables & Correlation \\
\hline Extractives - Holocellulose & -0.6937 \\
Ash - Volatile materials & -0.9550 \\
Ash - Higher calorific value & -0.8052 \\
Ash - Carbon & -0.9045 \\
Ash - Hydrogen & -0.8387 \\
Ash - Oxygen & 0.9212 \\
Holocellulose - Higher calorific value & 0.6567 \\
Volatile materials - Higher calorific value & 0.7525 \\
Volatile materials - Carbon & 0.7782 \\
Volatile materials - Hydrogen & 0.8464 \\
Volatile materials - Oxygen & -0.8106 \\
Higher calorific value - Carbon & 0.7547 \\
Higher calorific value - Hydrogen & 0.7604 \\
Higher calorific value - Oxygen & -0.7643 \\
Carbon - Hydrogen & 0.7140 \\
Carbon - Oxygen & -0.9793 \\
Hydrogen - Oxygen & -0.8076 \\
Nitrogen - C/N ratio & -0.7056 \\
Carbon - C/H ratio & 0.6704 \\
C/H ratio - C/N ratio & 0.7263 \\
\hline
\end{tabular}

A high positive correlation was found of higher calorific value with volatile materials, carbon and hydrogen contents, and a high negative correlation was found of higher calorific value with oxygen content.

A high correlation was expected of lignin, extractives and fixed carbon contents with higher calorific value, despite results. This is possibly due to the great variability in residues used in this study. Holocellulose content, however, was found to have a moderate, positive correlation with higher calorific value.

\section{CONCLUSIONS}

In general, all residues showed good potential for use in energy generation. In the elemental analysis, the carbon content varied within the range expected for lignocellulosic materials, except for rice husk. This latter residue showed higher lignin content, but also high ash and oxygen contents and low carbon content,

Cerne, Lavras, v. 17, n. 2, p. 237-246, abr./jun. 2011 
which probably led to a reduction in calorific value and fixed carbon content. The remaining residues showed similar characteristics, with special mention of corn cob which showed greater calorific value, followed by coffee plant stem. All residues showed high levels of volatile materials and low levels of fixed carbon. Higher calorific value had a high positive correlation with volatile materials, carbon and hydrogen contents, and a negative correlation with oxygen content. An alternative way of improving the energetic properties of residues, reducing the level of volatile materials and increasing the calorific value, is applying torrefaction to residues or blending them with fine charcoal particles.

\section{REFERENCES}

ASSOCIAÇÃO BRASILEIRA DE NORMAS TÉCNICAS. NBR 8112: carvão vegetal: análise imediata. Rio de Janeiro, 1983. 6 p.

\section{ASSOCIAÇÃO BRASILEIRA DE NORMAS TÉCNICAS.}

NBR 8633: carvão vegetal: determinação do poder calorífico. Rio de Janeiro, 1984. 13 p.

\section{ASSOCIAÇÃO BRASILEIRA TÉCNICA DE CELULOSE E PAPEL. Normas técnicas ABCP. São Paulo, 1974. 6 p.}

BIANCHI, M. L. Polpação de palha de milho utilizando-se diferentes processos organosolv. 1995. 76 p. Dissertação (Mestrado em Química) - Universidade Estadual de Campinas, Campinas, 1995.

BOSE, M. L. V.; MARTINS FILHO, J. G. O papel dos resíduos agroindustriais na alimentação de ruminantes. Informe Agropecuário, Belo Horizonte, v. 10, n. 119, p. 3-7, nov. 1984.

BRAHAN, J. E.; BRESSANI, R. Pulpa de café: composición, tecnologia y utilización. Bogota: INCAP, 1978. 10 p.

BRITO, J. O. Expressão da produção florestal em unidades energéticas. In: CONGRESSO FLORESTAL PANAMERICANO, 1.; CONGRESSO FLORESTAL BRASILEIRO, 7., 1993, Curitiba. Anais... Curitiba: UFPR, 1993. v. 3, p. 280-282.

BRITO, J. O.; BARRICHELO, L. E. G. Características do eucalipto como combustível: análise química imediata da madeira e da casca. IPEF, Piracicaba, n. 16, p. 63-70, 1978.
BRUM, S. S. Caracterização e modificação química de resíduos sólidos do beneficiamento do café para produção de novos materiais. 2007. 138 p. Dissertação (Mestrado em Agroquímica) - Universidade Federal de Lavras, Lavras, 2007.

BRUM, S. S.; BIANCHI, M. L.; SILVA, V. L. da; GONÇALVES, M.; GUERREIRO, M. C.; OLIVEIRA, L. C. A. Preparação e caracterização de carvão ativado produzido a partir de resíduos do beneficiamento do café. Química Nova, São Paulo, v. 31, n. 5, p. 1048-1052, 2008.

BRUM, S. S.; SILVA, V. L.; BIANCHI, M. L.; REIS, M. C. Caracterização química do resíduo da colheita de feijão (palha de feijão). In: CONGRESSO DOS PÓS-GRADUANDOS DA UNIVERSIDADE FEDERAL DE LAVRAS, 15., 2006, Lavras. Anais... Lavras: UFLA, 2006. CD-ROM.

CHAGAS, E.; ARAÚJO, A. P.; TEIXEIRA, M. G.; GUERRA, J. G. M. Decomposição e liberação de nitrogênio, fósforo e potássio de resíduos da cultura do feijoeiro. Revista Brasileira de Ciências do Solo, Viçosa, v. 31, n. 4, p. 723729, jul./ago. 2007.

CRUZ, J. M.; DOMÍNGUEZ, J. M.; DOMÍNGUEZ, H.; PARAJÓ, J. C. Preparation of fermentation media from agricultural wastes and their bioconversion to xylitol. Food Biotechnology, New York, v. 14, p. 79-97, 2000.

DINIZ, J.; CARDOSO, A. L.; STAHL, J. A.; VILLETTI, M. A.; MARTINS, A. F. Poder calorífico da casca de arroz, caroço de pêssego, serragem de eucalipto e de seus produtos de pirólise. Revista Ciência e Natura, Santa Maria, v. 26, n. 2, p. 25-32, 2004.

FURLANI, P. R.; GALLO, J. R. Determinação de silício em material vegetal pelo método colorimétrico do "azul-demolibdênio”. Bragantia, Campinas, v. 37, n. 2, p. 5-9, jan. 1978.

\section{INSTITUTO BRASILEIRO DE GEOGRAFIA E} ESTATÍSTICA. Séries estatísticas e séries históricas. Rio de Janeiro, 2006. Disponível em: <http://www.ibge.gov.br/series_ estatisticas/tema.php?idtema=1>. Acesso em: 20 jan. 2010.

JENKINS, B. M. Fuel properties for biomassa materials. In: INTERNATIONAL SYMPOSIUM ON APPLICATION AN MANAGEMENT OF ENERGY IN AGRICULTURE: THE ROLE BIOMASS FUELS, 1., 1990, New Delhi. Proceedings... Ludhiana: Punjab Agricultural University, 1990. p. 21-23. 
LIMA, E. G. de; SILVA, D. A. da. Resíduos gerados em indústria de móveis de madeira situados no pólo moveleiro de Arapongas, PR. Revista Floresta, Curitiba, v. 35, n. 1, p. 105116, jan./abr. 2005.

MACEDO, I. C. de. Geração de energia elétrica a partir de biomassa no Brasil: situação atual, oportunidades e desenvolvimento. Brasília: Secretaria Técnica do Fundo Setorial de Energia-Centro de Gestão e Estudos Estratégicos, 2001. Disponível em: <http:www.cgee.org.br>. Acesso em: 29 set. 2009.

MARABEZI, K.; CHRISTOFOLETTII, G. B.; GURGEL, L. V. A.; ZAMBON, M. D.; ARANTES, T. M.; CURVELO, A. A. S. Determinação de lignina em bagaço e palha de cana-de-açúcar. In: REUNIÃO ANUAL DA SOCIEDADE BRASILEIRA DE QUÍMICA, 32., 2009, Fortaleza. Anais... Fortaleza, 2009. CD-ROM.

MORI, F. A.; MENDES, L. M.; TRUGILHO, P. F.; CARDOSO, M .G. Utilização de madeiras de Eucalyptus e nativas no armazenamento da aguardente de cana de açucar. In: SEMINÁRIO SUL-MINEIRO DE CACHAÇA DE ALAMBIQUE, 1., 2002, Lavras. Anais... Lavras: UFLA, 2002. p. 32-32.

MUNALULA, F.; MEINCKEN, M. An evaluation of South African fuelwood with regards to calorific value and environmental impact. Biomass and Bioenergy, Cambridge, v. 33, n. 3, p. 415-420, Mar. 2009.

OLIVEIRA, L. K. Desenvolvimento de materiais adsorventes de óleos a partir de resíduos da agroindústria e sua aplicação na ração de aves. 2009. 74 p. Dissertação (Mestrado em Agroquímica) - Universidade Federal de Lavras, Lavras, 2009.

PEREIRA, M. A. Confecção de móveis com a madeira de Coffea arabica L. 2008. 59 p. Dissertação (Mestrado em Ciência e Tecnologia da Madeira) - Universidade Federal de Lavras, Lavras, 2008.

PITARELO, A. P. Avaliação da susceptibilidade do bagaço e da palha de cana-de-açúcar à bioconversão via prétratamento a vapor e hidrólise enzimática. 2007. 125 p. Dissertação (Mestrado em Química) - Universidade Federal do Paraná, Curitiba, 2007.

QUIRINO, W. F. Utilização energética de resíduos vegetais. Brasília: LPF/IBAMA, 2003. 14 p.
QUIRINO, W. F.; VALE, A. T.; ANDRADE, A. P. A.; ABREU, V. L. S.; AZEVEDO, A. C. S. Poder calorífico da madeira e de materiais lignocelulósicos. Revista da Madeira, São Paulo, n. 89, p. 100-106, 2005.

RAVEENDRAN, K.; GANESH, A.; KHILAR, K. C. Influence of mineral matter on biomass pyrolysis characteristics. Fuel, Amsterdam, v. 74, p. 12-22, 1995.

REYES, J.; PERALTA-ZAMORA, P.; DURÁN, N. Hidrólise enzimática de casca de arroz utilizando-se celulases, efeito de tratamentos químicos e fotoquímicos. Química Nova, São Paulo, v. 21, n. 2, p. 140-143, 1997.

RIBEIRO, A. S.; ANDRADE, A. M. de. Carbonização de resíduos do processamento mecânico da madeira de eucalipto. Ciência Florestal, Santa Maria, v. 15, n. 1, p. 1-7, 2005.

ROCHA, F. C.; GARCIA, R.; FREITAS, A. W. P.; SOUZA, A. L.; GOBBI, K. F.; VALADARES FILHO, S. C.; TONUCCI, R. G.; ROCHA, G. C. Casca de café em dietas para vacas em lactação: consumo, digestibilidade, produção e composição de leite. Revista Brasileira de Zootecnia, Viçosa, v. 35, n. 5, p. 2163-2171, 2006.

SALAZAR, R. F. S.; SILVA, G. L. P.; SILVA, M. L. C. P. Estudo da composição da palha de milho para posterior utilização como suporte na preparação de compósitos. In: CONGRESSO BRASILEIRO DE ENGENHARIA QUÍMICA EM INICIAÇÃO CIENTÍFICA, 6., 2005, Campinas. Anais... Campinas: Unicamp, 2005. CD-ROM.

SEYE, O.; CORTEZ, L. A. B.; GÓMEZ, E. O. Estudo cinético da biomassa a partir de resultados termogravimétricos. In:

Energia no meio rural. [S.l.: s.n.], 2003. Disponível em: <http:// www.proceedings.scielo.br/scielo.php?pid=MSC0000000022000 000200022\&script=sci_arttext $>$. Acesso em: 19 out. 2009.

SILVA, A. M.; BENTES, M. A.; MEDRADO, S. B.; CARVALHO JÚNIOR, J. A. Estudo da utilização da biomassa em substituição parcial ao carvão mineral na fabricação do coque na coqueira da CSN. Revista Tecnologia em Metalurgia e Materiais, São Paulo, v. 5, n. 1, p. 40-45, jul./set. 2008.

SOUZA, R. C. R.; SEYE, O.; SANTOS, E. C. S.; MORAIS, M. R.; DINIZ, J. T. A.; BARROS, A. O.; BARROSO, L. N. Estudo do aproveitamento de biomassa para produção de eletricidade no Estado de Roraima: relatório final. Manaus: CDEAM/UFAM, 2005. 43 p.

Cerne, Lavras, v. 17, n. 2, p. 237-246, abr./jun. 2011 
TRUGILHO, P. F.; LIMA, J. T.; MORI, F. A. Correlação canônica das características químicas e físicas de clones de Eucalyptus grandis e Eucalyptus saligna. Cerne, Lavras, v. 9, n. 1, p. 66-80, 2003.
VALE, A. T.; GENTIL, L. V. Produção e uso energético de biomassa e resíduos agroflorestais. In: Tecnologias aplicadas ao setor madeireiro III. Rio Branco: Suprema, 2008. p. 195-241.

Cerne, Lavras, v. 17, n. 2, p. 237-246, abr./jun. 2011 